\title{
Should project management aspire to be an archetypal profession: Evidence from Australian-based research
}

\author{
Dr. Julien Pollack \\ Senior Lecturer \\ University of Technology, Sydney \\ Julien.pollack@uts.edu.au \\ Phone: 95148632 \\ Fax: 95148777
}

\author{
Dr. Chivonne Algeo \\ Senior Lecturer \\ University of Technology, Sydney \\ Chivonne.algeo@uts.edu.au \\ Phone: 95148727 \\ Fax: 95148777
}

\begin{abstract}
:
Many occupations aspire to recognition as a profession. The question of whether or not project management is a profession has arisen multiple times within the literature, but answers vary. It is possible to identify common traits that typify occupations that are consistently agreed to have professional status. Project management is reviewed against these professional traits.
\end{abstract}

This study also reports on the findings of two surveys, which provide insight into project managers' perceptions of their own field. Survey responses are compared to their perceptions of change management, an arguably comparable field. Then, project managers' views are compared to the general public's perception of project management.

It is found that a number of the archetypal traits of professions may not be relevant or desirable for project management. However, some approaches for developing the image of the field of project management to professional status are identified and discussed.

\section{Keywords:}

Project management, profession, ethics, licensure, specialisation, occupation, status 
Cite as: Pollack, J. Algeo, C. (2015) Should project management aspire to be an archetypal profession: Evidence from Australian-based research. International Journal of Project Organization and Management, 7(4), 352-368. DOI: 10.1504/IJPOM.2015.073140

\section{Introduction}

Project management originated in the construction, defence and aerospace industries. However, project management has spread past these industries to now be a key approach to delivering the full range of organisational objectives, from information systems development, to organisational change and new product development. Project management is recognised as a management practice that has consistency across application areas, with practitioners who view their career development in terms of their project management, rather than their industry, expertise. However, there has been little critical attention paid to this shift as far as the professional status of the field is concerned (Hodgson, 2002, p. 803). This paper reviews the status of project management as a profession independent of industry.

Many occupations aspire to recognition as a profession. Such aspiration can be motivated by a desire to "....increase the status, rewards and prestige..." (Sheen \& Stevens, 2002, p. 187), "...to increase the income of professionals..." (Gravelle, 1985, p. 1052) and in the belief "...that they deserve more pay and more honour than they receive" (Moline, 1986, p. 502). Examples of similar debates in other fields abound, from management consultancy (Muzio, 2011), psychology (Peterson, 1976), and auditing (De Beelde, 2002), to aromatherapy (Sheen \& Stevens, 2002). This move of occupations to professional status is not new. Indeed, in 1964 the phenomenon was recognized in a paper published with the title "The Professionalization of Everyone?" (Wilensky, 1964).

The professional status of project management has previously arisen in the literature. Authors do not agree on the answer to this question, with some calling project management “...a recognized profession" (Wang, 2002, p. 7), and others more cautiously noting that "... project management has not yet achieved most of the characteristics of a traditional profession" (Zwerman \& Thomas, 2006, p. 238).

More consistently, the field is classified as an emerging profession (Helgadottir, 2008, p. 743) or a semi-profession (Morris, Crawford, Hodgson, Shepherd, \& Thomas, 2006), an occupation which aspires to professional status. This classification distinguishes project management from the traditional professions of physicians, religious orders and lawyers; professions which Moline (1986) refers to as the Paradigm Professions; professions which have set the archetype against which other occupations are compared in the sociological literature (e.g. Abbott, 2001; Hinings, 2001).

\section{The traits of the Paradigm Professions}

The traits of the Paradigm Professions are variously described (Table 1). Although themes exist, much variety remains. These traits are interpretations of the Paradigm Professions, rather than unanimously agreed definitions.

Such traits have been used to identify changes needed in project management to become more like these archetypal professions. Morris et al (2006) focus on the role of bodies of knowledge in professions. Helgadottir (2008) presents the view that explicit discussion of ethical standards is a necessary next step in the professionalization of the field. Wang (2002) focuses on the need for project management values to become central identifying factors in project managers lives. These traits will be discussed throughout this paper, with reference to survey results, where appropriate. 
Cite as: Pollack, J. Algeo, C. (2015) Should project management aspire to be an archetypal profession: Evidence from Australian-based research. International Journal of Project Organization and Management, 7(4), 352-368. DOI: 10.1504/IJPOM.2015.073140

\begin{tabular}{|c|c|c|c|}
\hline $\begin{array}{l}\text { Hinings (2001, p. } \\
\text { 12160) citing } \\
\text { Greenwood (1956) }\end{array}$ & $\begin{array}{l}\text { Morris et al (2006, p. } \\
\text { 711) citing Roach } \\
\text { Anleu (1992) and } \\
\text { Hugman (1991) }\end{array}$ & $\begin{array}{l}\text { Zwerman \& Thomas } \\
\text { (2006, p. 237) citing } \\
\text { Roach Anleu (1992) } \\
\text { and Hugman (1991) }\end{array}$ & $\begin{array}{l}\text { Cheetham \& Chivers } \\
(2005, \text { p. 20) }\end{array}$ \\
\hline $\begin{array}{l}\text { Professional culture } \\
\text { Codes of ethics }\end{array}$ & Code of ethics & Altruistic & $\begin{array}{l}\text { Non-commercial } \\
\text { Code of ethics } \\
\text { Altruistic }\end{array}$ \\
\hline Prolonged training & Formal education & & $\begin{array}{l}\text { Prolonged and } \\
\text { specialised training }\end{array}$ \\
\hline Certification & Entry requirements & & \\
\hline $\begin{array}{l}\text { Community sanction } \\
\text { and legitimation }\end{array}$ & & $\begin{array}{l}\text { Distinctive } \\
\text { occupational culture }\end{array}$ & $\begin{array}{l}\text { Professional body } \\
\text { Self-regulatory } \\
\text { Collegial }\end{array}$ \\
\hline \multirow[t]{2}{*}{ Recognized authority } & & Recognition & $\begin{array}{l}\text { Status within society } \\
\text { Influence within } \\
\text { society }\end{array}$ \\
\hline & Autonomy of practice & Autonomy of practice & Autonomy of practice \\
\hline \multirow[t]{2}{*}{ Systematic theory } & $\begin{array}{l}\text { Discrete body of } \\
\text { knowledge }\end{array}$ & $\begin{array}{l}\text { Esoteric and } \\
\text { systematic BOK }\end{array}$ & \\
\hline & Service ideals & Authority over clients & Client-focused \\
\hline
\end{tabular}

Table 1: Comparison of interpretations of professional traits

\section{Methodology}

Two different surveys are referred to in this paper, the results of which will aid discussion of this topic. Both surveys were conducted by anonymous internet distribution.

The first survey (the Project Managers' Survey) was conducted to gauge the opinions of project managers. The Australian Institute of Project Management (AIPM) and the Sydney Chapter of the Project Management Institute (PMI: Sydney) distributed a link to the survey to their members. The researchers also used their professional networks to encourage participation. There were 384 responses.

The second survey (the Vox Populi Survey) was conducted to gauge the general public response to a limited subset of the questions in the Project Managers' Survey. Survey participation was requested from employees of the university where both authors are employed. Given the range of subjects taught at this university and the variety of employees' managerial and administrative duties, this sample was considered sufficiently broad, for the purposes of this study. There were 247 responses.

\section{Demographic of the surveyed project managers}

In the Project Managers' Survey, $220(57.3 \%)$ respondents identified themselves as a Project Manager (including junior, senior, committee, and sponsor positions). This subset will be referred to as the Surveyed Project Managers. The majority (88.6\%) had primarily gained their experience in Australia, followed by the United Kingdom (6.4\%). Surveyed Project Managers had an average of 11 years of work experience. The three most frequently cited industries in response to the question, "In which industry did you primarily gain your experience?" were IT (21.7\%), Finance / Insurance (13.1\%), and Government / Public Administration (12.6\%). 
The Surveyed Project Managers identified their highest level of project management qualification. The mode response was Diploma level qualification (19.1\%), followed by Masters with more than $50 \%$ focus on project management $(18.2 \%)$, followed by Masters with less than $50 \%$ focus on project management $(10.5 \%)$. They also identified their familiarity with other aspects of the field on a seven-point scale, with seven representing familiarity 'To a Very Great Extent'. Mean and median responses were:

- $\quad$ PMBOK® (PMI, 2008): mean 6.02, median 6

- PRINCE2® (UK Government Cabinet Office, 2002): mean 4.57, median 5

- PMI: Sydney: mean 5.54, median 6

- AIPM: mean 6.04, median 7

The Surveyed Project Managers are clearly a group who consider themselves familiar with project management texts and industry associations. This group were asked "Is Project Management a profession?" and 96.8\% confirmed that it is.

\section{Ownership of the body of knowledge}

The process of the professionalization of an occupation can be thought of as beginning "... with the recognition by people that they are doing something that is not covered by other professions..." (Morris et al., 2006, p. 711). A Paradigm Profession has an ownership of an unique body of knowledge.

Morris et al (2006) review the role of professional association documentation in the professionalization of project management, and there are documents commonly referred as project management bodies of knowledge, produced by industry associations, such as, the "...PMBOK Guide ... a subset of the larger Project Management Body of Knowledge" (PMI, 2004, p. 12). There are also considerable differences between the industry association publications (Crawford, Pollack and England, 2008). The project management body of knowledge should be thought to encompass a broad academic and trade literature, not just the standards and guides published by industry associations, as some acknowledge.

A distinct body of knowledge is not sufficient in staking out a professional territory, unless the body of knowledge encompasses the majority of knowledge relevant to an application area, and Morris et al (2006, p. 713) acknowledge something similar, commenting that "... project management is never going to be able to claim a monopoly over a discrete body of knowledge." Although acknowledged ownership of the knowledge may be problematic, it appears that the issue for the professionalization of project management lies less in monopoly over a commonly agreed group of techniques or theories, than monopoly over an application area.

\section{Ownership of the application area}

Contest for project management's application area comes from other disciplines. PMI have acknowledged overlap between project management and general management (PMI, 1996, 2000, 2004). Other overlaps have been identified. For instance, change management occupies a similar vocational space as project management in organisational change projects. There "... is evidence of a degree of rivalry between project managers and change managers concerning who should be managing business change" (Crawford \& Nahmais, 2010, p. 405).

The presence of rival occupations in dispute over application areas can lead to 
Cite as: Pollack, J. Algeo, C. (2015) Should project management aspire to be an archetypal profession: Evidence from Australian-based research. International Journal of Project Organization and Management, 7(4), 352-368. DOI: 10.1504/IJPOM.2015.073140

confusion for those interested in resolving a problematic situation, rather than a particular management approach, diluting the authority that project management has over its application area. This is not an issue that is faced by the Paradigm Professions, where expertise in their application area is clearly acknowledged. The "...legitimacy of a profession rests upon its claims to monopolise expertise..." (Hodgson, 2002, p. 806). For instance, general medical practitioners and faith healers may occupy overlapping areas of application, but the weight of mainstream recognition rests clearly with the medical profession. Similarly, the advice of lawyers or members of religious orders are given considerably greater weight than that of the lay person in their area of expertise.

Zwerman and Thomas (2006) have identified that forming "...a professional association defines a 'competency territory' that members claim as their exclusive area of competence practice" (2006, p. 237). However, making a claim is not sufficient in securing a territory, especially when other occupations' claim the same territory.

\section{Industry associations and certification}

A group of like-minded practitioners coming together to form an industry association is a recognised trait of the Paradigm Professions, which can be traced back to the early guilds (Beaton, 2010). To become a member of an industry association, practitioners are typically required to possess, abide by and maintain specific professional standards. It is interesting to note that the industry associations that participated in the survey have different entry requirements. PMI has no stated criteria about qualifications or years of experience. AIPM requires information on qualifications and years of experience for some membership levels (Table 2). These differing entry requirements are reflected in the survey results. The Surveyed Project Managers reported that $54.3 \%$ were required to provide details of a specific number of years' experience to become a member of a project management association and $58.3 \%$ required a specific qualification.

To claim competency, a project manager can be certified according to established benchmarks; a trait of the Paradigm Professions. AIPM certifies members by workplace competence demonstrated through a portfolio of work-based evidence. PMI uses a knowledge-based test to demonstrate capability, with demonstrated experience required before the test is taken.

\begin{tabular}{|c|c|c|}
\hline & AIPM & PMI \\
\hline Entry level & $\begin{array}{l}\text { Certified Practising } \\
\text { Project Practitioner }\end{array}$ & $\begin{array}{l}\text { The Certified } \\
\text { Associate in Project } \\
\text { Management }\end{array}$ \\
\hline $\begin{array}{l}\text { Intermediate } \\
\text { Level }\end{array}$ & $\begin{array}{l}\text { Certified Practising } \\
\text { Project Manager }\end{array}$ & $\begin{array}{l}\text { The Project } \\
\text { Management } \\
\text { Professional }\end{array}$ \\
\hline Executive Level & $\begin{array}{l}\text { Certified Practising } \\
\text { Project Director }\end{array}$ & $\begin{array}{l}\text { Program } \\
\text { Management } \\
\text { Professional }\end{array}$ \\
\hline
\end{tabular}

Table 2: Professional Association Certification Levels

The consistent factor is that regardless of whether competence or knowledge is assessed, measures remain on one continuum from less to more knowledge or competence. 
Cite as: Pollack, J. Algeo, C. (2015) Should project management aspire to be an archetypal profession: Evidence from Australian-based research. International Journal of Project Organization and Management, 7(4), 352-368. DOI: 10.1504/IJPOM.2015.073140

\section{The wide scope of the field}

The breadth of scope of an occupation can have impact upon its attempts at professionalization. Wilensky (1964) noted that a field "... which is too general and vague or too narrow and specific provides a weak base for an exclusive jurisdiction" (1964, p. 137). There is considerable variety in the field of project management (Crawford \& Pollack, 2007). Evidence for project management's wide scope is also in the variety of categorisation systems available for understanding project types (e.g. Bubshait \& Selen, 1992; Floricel \& Miller, 2001; Turner \& Cochrane, 1993; Youker, 1999; Crawford \& Pollack, 2004).

This range of activities that count as a project can cause problems for a purchaser of project management services, with impact on recognition of claims to sole jurisdiction and professional status. Purchasing generic project management services does not guarantee that the services will be suited to all types of projects. Successful delivery of virtual IT projects may not develop the cultural sensitivities appropriate for a construction project. A private sector construction project manager may not easily transfer into public sector organisational change. It is unlikely that most project managers will be experienced or competent in the full variety of projects.

The industry associations provide some distinction in certification, providing limited guidance for the purchaser of project management services. However, this single continuum of certification from beginner to expert is considerably different to the division of capability in the Paradigm Professions of law, medicine, and religion, which recognise clear specialisations by area of application, not just degree of capability, and are clearly descriptive to those seeking to acquire their services. It is transparent to the general public that while general medical practitioners and oncologists both operate within the medical profession, they provide different services. The purchaser of legal services may approach a criminal or tax lawyer, depending on where their issues lie, understanding that both lawyers have different capabilities. Similarly, a protestant is unlikely to approach a rabbi for advice about their religious concerns. The same cannot be said for project management, where industry association publications and training typically focus on aspects that are transferrable across all kinds of projects, and certification does not acknowledge divisions of specialisation.

\section{The ambiguous use of the title of project manager}

The purchaser of project management services may also be confused by the role of project managers. Project management may be applicable to large and small projects, but the title of project manager does not provide a clear indication of an individual's experience or capability. For instance, in one programme where one of the authors worked, the client-side manager of the multi-billion dollar programme was called the project manager. Simultaneously, the customer liaison of a minor supplier referred to himself as the project manager. Without context-specific knowledge, reliance on the position title would cause confusion, given the differences in authority and scope of the two project managers.

The Surveyed Project Managers were asked two questions relevant to an understanding of how ambiguous the title of project manager is. The Surveyed Project Managers were asked how much they agreed with the following statements on a seven point scale where one represents complete agreement.

Question: The position of Project Manager has clear roles and responsibilities in my organisation 
Cite as: Pollack, J. Algeo, C. (2015) Should project management aspire to be an archetypal profession: Evidence from Australian-based research. International Journal of Project Organization and Management, 7(4), 352-368. DOI: 10.1504/IJPOM.2015.073140

Mean response: 2.14

Standard deviation: 1.348

Median response: 2

Question: Project Managers do basically the same from organisation to organisation Mean response: 3.41

Standard deviation: 1.66

Median response: 3

From these results, it can be seen that although there is reasonable consistency within organisations, the Surveyed Project Managers perceived much greater variation between organisations. The higher standard deviation in the second question also suggests a greater variety of opinion.

Further confusion about project manager's roles comes from people using the title of project manager without explicit knowledge of the field. For instance, personnel with functional or technical expertise may be promoted to become a project manager as the next stage in their career. They may successfully deliver discrete pieces of work, referred to as projects, but without any reference to project management knowledge. Morris et al (2006, p. 713) noted that "...everywhere people are managing projects, more often than not without reference to any of the project management

associations' bodies of knowledge." Wang (2002, p. 8) also identified that the title of project manager "... is so widely and randomly used in an organizational context as a position title ... that its link to the PM profession is quite weak."

The Surveyed Project Managers were asked two questions relevant to this topic. On a seven-point scale, they were asked how much they agreed with the following, with one representing complete agreement.

Question: In my experience specialist knowledge is required to be a Project Manager Mean response: 2.08

Standard deviation: 1.13

Median response: 2

Question: Most people could be a Project Manager without dedicated training Mean response: 5.66

Standard deviation: 1.47

Median response: 6

These results show considerable agreement with the first statement and disagreement with the second. This indicates a consistent perception of the value of specialist training and education. However, agreement within the industry about the need for specialist training will not prevent those without training from being called a project manager.

\section{Occupational licensure}

One response to the unregulated use of the title project manager is to legally restrict its use, such as by government licensure. Some consider that this would contribute to the professional status of project management. "To attain professional status, professional associations must be given legal responsibility for designating who is qualified to practice" (Zwerman \& Thomas, 2006, p. 242). However, it is unclear whether licensure of project management is desirable. Although licensing the term project manager may cement the association of the term with association membership, other impacts are uncertain. Licensure is no guarantee of increased wages within an occupation (White, 1978, p. 93), and "...may actually reduce quality" (Gravelle, 1985, p. 1053). Licensure can also result in increased legal liability for 
Cite as: Pollack, J. Algeo, C. (2015) Should project management aspire to be an archetypal profession: Evidence from Australian-based research. International Journal of Project Organization and Management, 7(4), 352-368. DOI: 10.1504/IJPOM.2015.073140

practitioners (Zwerman \& Thomas, 2006, p. 245).

Milton Friedman (1962) has also questioned the popularity of licensure, as it is rarely the users of a service who pressure legislature for licensure. Instead, "...the pressure invariably comes from the members of the occupation itself" (1962, p. 140), seeking to monopolise an application area. Friedman noted that "...certification without licensure is a half-way house that maintains a good deal of protection against monopolization" (1962, p. 149) and found "...it difficult to see any case for which licensure rather than certification can be justified" (1962, p. 149). Morris et al (2006, p. 714) have also identified practical difficulties with enforcing project management licensure, based on the wide range of people managing projects. Given the practical difficulties and uncertain benefits of licensure, licensing the use of the term project manager as a way of defining the role and therefore the profession may be an inappropriate course of action.

\section{Client relationship and autonomy of the role}

The Paradigm Professions are also typified by relationships with their clients extending beyond simple service provision; a relationship that is affected by information asymmetry, a personal relationship, a fiduciary responsibility, and autonomy.

Professionals typically have significantly greater specialist expertise than their clients, which could be exploited by the unscrupulous. This information asymmetry "...leads to the development of a set of professional ethics which stress the professionals' duty to his client and forbids him to exploit the client's inability to monitor his behaviour" (Gravelle, 1985, p. 1052). However, unlike the Paradigm Professions, there is arguably low information asymmetry between project managers and their clients. To some extent, this obviates the need for strict ethical codes designed to prevent exploitation of a client's ignorance.

Associated with this personal relationship is a sense of responsibility; a fiduciary relationship, where it is assumed that the professional will act in the best interests of the client (Moline, 1986, p. 503). To uphold this fiduciary responsibility to act in the best interests of the client, the professional must be allowed to act autonomously, unfettered by conflicting commitments.

The question then arises about whether it is possible for an occupation to attain the status of a profession if the practitioners predominantly provide their services to organisations, rather than to individuals. It has been claimed that "...the notion of a professional encompasses values and cultural statements that are inimical to the forms of hierarchically organized, profit-driven corporations" (Hinings, 2001, p. 12164). The potential for conflict between the project management ethical standards and organisational roles has also been identified in the literature (Wang \& Armstrong, 2004; Zwerman \& Thomas, 2006). Some authors “...doubt the possibility for any occupation in the contemporary context achieving the supposed autonomy and status of the traditional professions at their peak" (Morris et al., 2006, p. 711).

Given a strong project management ethical code, project managers could face ethical conflicts in some situations. When working directly for the organisation delivering the project, conflict between the occupation's ethical code and the client's should be less significant. The relationship would be similar to that of an autonomous in-house lawyer employed by an organisation, but expected to maintain the ethical standards consistent with their profession. 
Cite as: Pollack, J. Algeo, C. (2015) Should project management aspire to be an archetypal profession: Evidence from Australian-based research. International Journal of Project Organization and Management, 7(4), 352-368. DOI: 10.1504/IJPOM.2015.073140

Complication arises when the client is a third party. In this case, it is not clear whether the project manager's services are being provided to the organisation that employs the project manager, or the customer organisation that contracts these services. The project manager may become a servant of two masters. This relationship becomes similar to a doctor given patient care instructions by a hospital administration that contradicts the medical professional standards. Here, it is not necessarily constraint of autonomy to act in accordance with an ethical code that becomes an issue. The difficulty lies is applying this code equally to multiple parties at once, each with different needs.

It is also reasonable to ask whether autonomy to act in accordance with an independent ethical code is valued by the purchaser of project management services. It is unclear whether project management services would be considered more valuable if project managers consistently insisted on an ethical code that may clash with the local ethics of an organisation. Advocating an ethical code at odds with an organisational culture may hamper a project manager's ability to deliver within that environment. It is worth considering whether it is appropriate for project management to strive for the ethical autonomy exhibited by the Paradigm Professions.

\section{A self-regulated, non-commercial ethical code of conduct}

The professional associations of the Paradigm Professions typically require compliance to a code of conduct. The consequences for noncompliance would usually involve expulsion and loss of status in the field. This emphasis can be seen in the definition of a profession provided by Professions Australia (PA, 1997):

"It is inherent in the definition of a profession that a code of ethics governs the activities of each profession. Such codes require behaviour and practice beyond the personal moral obligations of an individual. ... Further, these codes are enforced by the profession and are acknowledged and accepted by the community."

The pursuit of ethical standards can be seen in the various oaths that practitioners pledge to as they join a profession. For example, The World Medical Association was established in 1947 to update the Hippocratic Oath, now referred to as the Declaration of Geneva. This was adopted in 1948 in response to the atrocities that occurred in the Second World War. The World Medical Association was also tasked with developing an International Code of Ethics, where a Physician "....shall respect the local and national codes of ethics" (WMA, 2006).

Project Managers need to understand and abide by the legal and cultural requirements where they are conducting their work to minimise conflict. Simultaneously they need to be aware that unethical practices can result in financial losses for an organisation. Unethical behaviour was found by Cialdini, Petrova and Goldstein (2004) to result in reputation degradation, mismatches between values of employee and organisation, and increased surveillance. Furthermore, Rao and Long (1995, p. 72) have identified a tendency for significant shareholder losses after unethical behaviour was announced.

Given the potential negative impacts of unethical behaviour, unscrupulous members of professional associations could bring an association into disrepute. To minimise this, most associations have complaints procedures to ensure appropriate member conduct. The AIPM publishes a Code of Ethics that underpins a Code of Professional Conduct (AIPM, 2011). Members of the PMI abide by a Code of Ethics and 
Cite as: Pollack, J. Algeo, C. (2015) Should project management aspire to be an archetypal profession: Evidence from Australian-based research. International Journal of Project Organization and Management, 7(4), 352-368. DOI: 10.1504/IJPOM.2015.073140

Professional Conduct (2011) that identifies expectations for practitioners at work, at home and in service in the global community.

To ensure a code of conduct is maintained by an association a clearly defined grievance policy, with appropriate levels of authority to remove a member from the association, is necessary. The PMI provide a detailed Complaint, Dispute, and Grievance Policy (2010) to members with escalation steps that are managed confidentially. The process to expel an AIPM member is not publically available, however the AIPM has several detailed items in the association's Constitution (AIPM, 2008).

The Surveyed Project Managers reported that $77.3 \%$ knew that their primary association had a code of conduct. This would appear to be an issue. Furthermore, $44.5 \%$ of Surveyed Project Managers answered that their primary association did not have, or they did not know if it had, a complaints or disciplinary process. To ensure a code of conduct is effective, members need to be aware of the policy for managing complaints and understand that the associations have the authority to expel a member according to a clearly defined procedure. Unfortunately, $63.6 \%$ of Surveyed Project Managers answered that their primary association did not expel members who did not uphold the required conduct, or that they did not know whether members were expelled.

The results from the survey indicate that there are inconsistencies in the understanding and application of a code of conduct being used to manage members' behaviour. Ethical standards for the field do not appear to be highly significant to membership in project management associations, which brings into question whether project management can claim to exhibit this trait of the Paradigm Professions. This is consistent with observations from the literature. "Unlike the traditional professions, project management draws very little of its legitimacy by reference to its contribution to the public good, to an ideal of social service, or by adherence to an overarching ethical code" (Morris et al., 2006, p. 711).

\section{Project manager's perceptions of a comparable occupation}

It can be illuminating to compare the perceptions that the Surveyed Project Managers have of project management to their perceptions of a similar occupation. Change management was chosen as a point of comparison. The significance of change management to project management has been recently acknowledged in the literature, e.g. (Crawford, 2011; Crawford \& Nahmais, 2010; Gareis, 2008, 2010; Garfein \& Sankaran, 2011). Change management also shares many similarities with project management, as far as measurement against the traits of the Paradigm Professions are concerned.

Although change management does not have a widely accepted document named a 'Body of Knowledge', the field arguably has a distinct body of literature, significantly contributed to by Kotter (1996) and the Prosci Group (Hiatt, 2006). Change management professional associations exist, such as the Change Management Institute (CMI), which accredit practitioners using competency-based assessments comparable to that used by some project management industry associations. The $\mathrm{CMI}$ also maintains a complaints and disciplinary procedure for members. Change managers also have a similar relationship to their clients as project managers.

The Surveyed Project Managers were asked a similar series of questions about their perspectives of change management. On a seven-point scale, Surveyed Project Managers were asked how much they agreed with the following statements, with one 
Cite as: Pollack, J. Algeo, C. (2015) Should project management aspire to be an archetypal profession: Evidence from Australian-based research. International Journal of Project Organization and Management, 7(4), 352-368. DOI: 10.1504/IJPOM.2015.073140

representing complete agreement. Answer options allowed for a "Not applicable" response. Responses are summarised in Table 3.

\begin{tabular}{|l|l|c|c|c|}
\hline Group & Question & Mean & Std. Dev. & Median \\
\hline 1 & $\begin{array}{l}\text { In my experience specialist knowledge is required } \\
\text { to be a Project Manager }\end{array}$ & 2.08 & 1.13 & 2 \\
\cline { 2 - 4 } & $\begin{array}{l}\text { In my experience specialist knowledge is required } \\
\text { to be a Change Manager }\end{array}$ & 2.4 & 1.185 & 2 \\
\hline 2 & $\begin{array}{l}\text { Most people could be a Project Manager without } \\
\text { dedicated training }\end{array}$ & 5.66 & 1.47 & 6 \\
\cline { 2 - 5 } & $\begin{array}{l}\text { Most people could be a Change Manager without } \\
\text { dedicated training }\end{array}$ & 5.5 & 1.434 & 6 \\
\hline 3 & $\begin{array}{l}\text { Project Managers do basically the same from } \\
\text { organisation to organisation }\end{array}$ & 3.41 & 1.66 & 3 \\
\cline { 2 - 5 } & $\begin{array}{l}\text { Change Managers do basically the same from } \\
\text { organisation to organisation }\end{array}$ & 3.77 & 1.489 & 4 \\
\hline 4 & $\begin{array}{l}\text { The position of Project Manager has clear roles } \\
\text { and responsibilities in my organisation }\end{array}$ & 2.14 & 1.348 & 2 \\
\cline { 2 - 5 } & $\begin{array}{l}\text { The position of Change Manager has clear roles } \\
\text { and responsibilities in my organisation }\end{array}$ & 3.79 & 1.701 & 4 \\
\hline
\end{tabular}

Table 3: Surveyed Project Managers perceptions of project management and change management

Responses to the group 1 and 2 questions in Table 3 indicate that the Surveyed Project Managers consider that specialist knowledge is more typically required to be a project manager than a change manager, and that it is more likely that anyone could be a change manager than a project manager without specialist training. The responses to the group 3 questions indicate that the Surveyed Project Managers saw more consistency in project management than change management roles from organisation to organisation. However, the strongest differences in responses were seen in the responses to the group 4 questions in Table 3 . These results show that the Surveyed Project Managers considered change managers' roles to be significantly less well defined than project management roles within their organisations. Overall, these results can be taken to indicate that the Surveyed Project Managers considered specialist knowledge to be less significant for change management than project management, and that they considered the field of change management to be less consistent than project management.

Given these results, it was not surprising that the Surveyed Project Managers were less likely to consider change management to be a profession than project management. When asked "Is Change Management a profession?" the Surveyed Project Managers responded as shown in Table 4:

\begin{tabular}{|l|c|c|}
\hline Answer & Is Project Management a profession? & $\begin{array}{l}\text { Is Change Management a } \\
\text { profession? }\end{array}$ \\
\hline Yes & $96.8 \%(213)$ & $63.2 \%(139)$ \\
\hline No & $3.2(7)$ & $23.2 \%(51)$ \\
\hline Don't know & $0(0)$ & $13.6 \%(30)$ \\
\hline
\end{tabular}

Table 4: Is change management a profession?

It is interesting to note the difference in perceived professional status, given the similarities between project management and change management. Both occupations have distinct associated literatures, industry associations and are applied in fields with significant overlap. These two fields have similar traits when 
Cite as: Pollack, J. Algeo, C. (2015) Should project management aspire to be an archetypal profession: Evidence from Australian-based research. International Journal of Project Organization and Management, 7(4), 352-368. DOI: 10.1504/IJPOM.2015.073140

measured against the Paradigm Professions, but are perceived differently.

One possible explanation of the results rests with the sample group. It is arguable that project managers are best positioned to understand the value of the services they provide, and may not be as aware of the benefits that change management can provide. Having invested significant personal time and effort developing project management competence, it is also possible that some Surveyed Project Managers may have developed a preference for the field, viewing it as superior to other fields due to their invested effort. One conclusion that can be drawn from this is that it not necessarily alignment with the traits of a Paradigm Profession that lead an occupation to be regarded as a profession.

\section{The general perception of project management}

The trait-based perspective of professionalization of a field views an occupation as independently striving for professional status through attainment and exhibition of the particular traits. Abbott (1988) provides a contrasting perspective, where the move towards acknowledgement of an occupation's professional status instead needs to be understood in terms of the "...complex facts of jurisdictional competition and interprofessional relationships" (Abbott, 1988, p. 23). Occupations attempted "...to claim control of work in the workplace, before the public, and within the state, and the course of professions histories was determined by the ensemble of this melee of interaction" (Abbott, 2001, p. 12168).

When viewed less as a title that can be claimed upon attainment of idealised traits, and more as the interaction between groups of people seeking to define and claim an area of practice, the significance of the general public perception of an occupation becomes more relevant. Viewed from this perspective, a prospective occupation may be able to claim and demonstrate attainment of all of the paradigmatic traits, but unless the general public consider the occupation to be a profession, any claim to be a profession will be in vain. "Any occupation wishing to exercise professional authority must ... convince the public that its services are uniquely trustworthy" (Wilensky, 1964, p. 138). Lack of public acceptance of an occupation as a profession explains why "...many occupations will assert claims to professional status and find that the claims are honoured by no one but themselves" (Wilensky, 1964, p. 142).

To start to understand the public perception of project management, a second survey was conducted, the Vox Populi Survey. No demographic data was collected from this survey. Participation was open to all of the authors' universities, which included approximately 3000 staff. This survey involved only two questions. The first question was "Is Project Management a profession?" These results are compared with those from the Project Managers' Survey in the Table 5 below. It is clear from these results that the general public were less likely to consider project management to be a profession than the Surveyed Project Managers were.

\begin{tabular}{|c|c|c|}
\hline Answer & Project Managers' Survey & Vox Populi Survey \\
\hline Yes & $96.8 \%(213)$ & $43 \%(107)$ \\
\hline No & $3.2(7)$ & $56 \%(138)$ \\
\hline
\end{tabular}

Table 5: Is Project Management a Profession?

The second question in the Vox Populi Survey was "How much do you agree with the statement: Specialist knowledge is required to be a Project Manager?" Responses to this question are summarised in Table 6 and Figure 1, and are compared to two questions from the Project Managers Survey: the equivalent question; and a question 
Cite as: Pollack, J. Algeo, C. (2015) Should project management aspire to be an archetypal profession:

Evidence from Australian-based research. International Journal of Project Organization and Management, 7(4), 352-368. DOI: 10.1504/IJPOM.2015.073140

regarding agreement with the statement "The general public think that specialist knowledge is required to be a Project Manager".

\begin{tabular}{|l|c|l|l|l|}
\hline Answer & Value & $\begin{array}{l}\text { Question 1: } \\
\text { Project Managers' } \\
\text { Survey } \\
\text { 'In my experience } \\
\text { specialist } \\
\text { knowledge is } \\
\text { required to be a } \\
\text { Project Manager' }\end{array}$ & $\begin{array}{l}\text { Question 2: } \\
\text { Project Managers' } \\
\text { Survey } \\
\text { 'The general } \\
\text { public think that } \\
\text { specialist } \\
\text { knowledge is } \\
\text { required to be a } \\
\text { Project Manager' }\end{array}$ & $\begin{array}{l}\text { Question 3: } \\
\text { Vox Populi } \\
\text { Survey } \\
\text { 'Specialist } \\
\text { knowledge is } \\
\text { required to be a } \\
\text { Project } \\
\text { Manager' }\end{array}$ \\
\hline Completely Agree & 1 & $37.7 \%(83)$ & $11.4 \%(25)$ & $24.7 \%(61)$ \\
\hline Agree & 2 & $31.8 \%(70)$ & $39.1 \%(86)$ & $32.4 \%(80)$ \\
\hline Somewhat Agree & 3 & $21.4 \%(47)$ & $25.5 \%(56)$ & $20.6 \%(51)$ \\
\hline $\begin{array}{l}\text { Neither Agree Or } \\
\text { Disagree }\end{array}$ & 4 & $4.5 \%(10)$ & $8.6 \%(19)$ & $6.9 \%(17)$ \\
\hline Somewhat Disagree & 5 & $3.2 \%(7)$ & $8.6 \%(19)$ & $6.5 \%(16)$ \\
\hline Disagree & 6 & $1.4 \%(3)$ & $5.0 \%(11)$ & $5.7 \%(14)$ \\
\hline Completely Disagree & 7 & 0 & $1.4 \%(3)$ & $3.2 \%(8)$ \\
\hline Mean & - & 2.08 & 2.84 & 2.7 \\
\hline Standard Deviation & - & 1.13 & 1.393 & 1.61 \\
\hline Median & - & 2 & 2 & 2 \\
\hline
\end{tabular}

Table 6: Is specialist knowledge required to be a project manager?

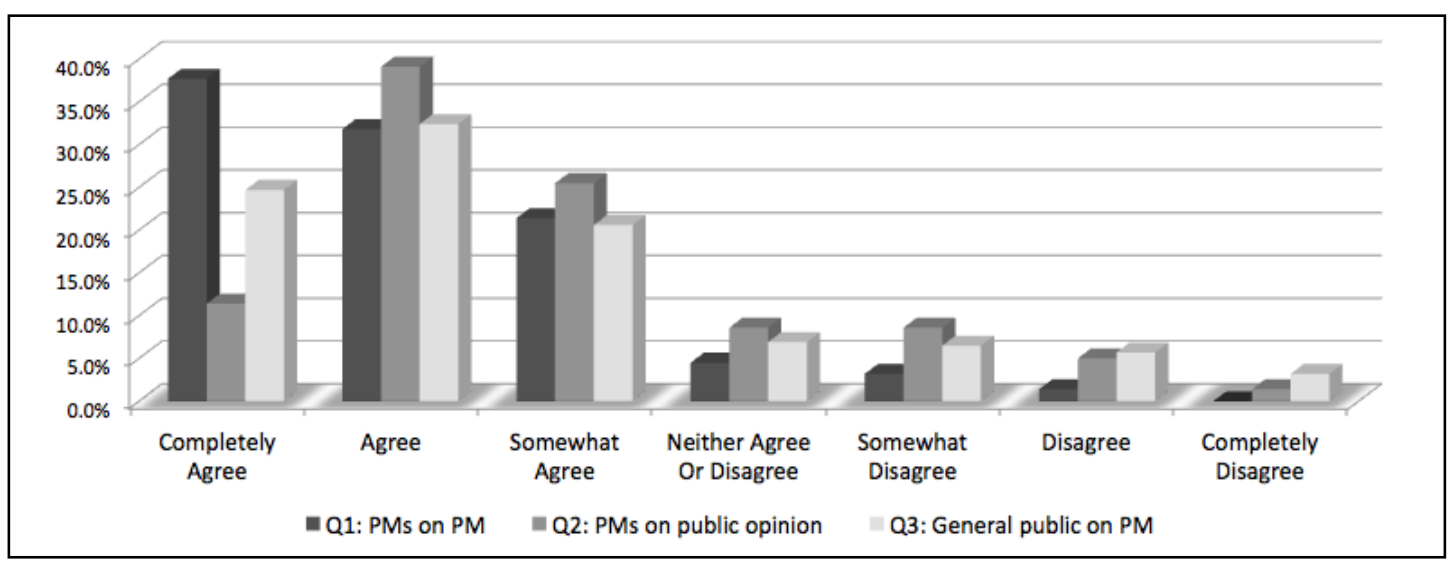

Figure 1: Is specialist knowledge required to be a project manager?

Generally, the people best placed to judge whether specialist knowledge is required to complete a task will be those with the most experience in it. In this case, it is likely that the results of the Project Managers' Survey will more accurately report whether specialist knowledge is required. However, as far as recognition of the profession is concerned, it is arguably just as important to understand how the occupation is perceived.

It is interesting to note that the results for Question 2 in Table 6 are very similar to the results for Question 3. This indicates that the Surveyed Project Managers view of the public perception of project management is relatively accurate. The Surveyed Project Managers seem to be aware that there is a general public perception that less specialist knowledge is required to be a project manager than they feel is actually required. This may suggest that project management has an image problem. 


\section{Conclusion}

This study has reflected upon the status of project management, as measured against the traits of the Paradigm Professions. Project management can be argued to have substantially met the following traits: ownership of a distinct body of knowledge; representative industry associations; certification; specialised training; and presence of ethical codes. However, the field does not meet the following traits of the Paradigm Professions: defined area of application; specialisation within the field; clear role nomenclature; and the prominence of ethical codes in informing practice.

A number of questions remain open regarding the desirability and applicability of other traits to project management. For instance, it is unclear whether increased ethical autonomy is desirable. Increased standing as a profession may also increase professional liability, something that is of uncertain benefit to project managers. Most importantly, it is unclear whether being considered a profession is in itself a desirable attribute. However, assuming that it is, it is important to note that the professionalization of project management is not a given. "Many occupations engage in heroic struggles for professional identification; few make the grade" (Wilensky, 1964, p. 137).

If the field does want to progress towards the status of a profession, then some areas for development have been identified in this study. For instance, recognition of specialised areas of practice is one trait common to the Paradigm Professions that some parts of the field seem to already be moving towards. The other central area that may contribute to the professionalization of the field rests in consideration that the title of 'profession' is one that is bestowed by the public at large, rather than one which is claimed by aspirants to that title. Such an approach may involve focusing on developing the perceived image of the field as a profession, and increasing public awareness of the benefits that project management can provide.

\section{References}

Abbott, A. (1988) The System of Professions. University of Chicago Press, Chicago.

Abbott, A. (2001) 'Sociology of Professions', in Smelser, N. \& Baltes, P. (Eds.), International Encyclopaedia of the Social and Behavioral Sciences, Elsevier, pp. 12166-12169.

AIPM (2008) AIPM Constitution, Australian Institute of Project Management.

AIPM (2011) Code of Ethics for the Project Management Industry, Retrieved 28 November 2011, from http://www.aipm.com.au/html/2010_code_of_ethics.cfm

Beaton, G. (2010) Why Professionalism is Still Relevant. Professions Australia.

Bubshait, A. and Selen, W. (1992) 'Project Characteristics that Influence the Implementation of Project Management Techniques: a survey', Project Management Journal, Vol. 23, No. 2, pp. 43-47.

Cialdini, .R, Petrova, P. and Goldstein, N. (2004) 'The Hidden Costs of Organisational Dishonesty', Sloan Management Review, No. Spring, pp. 67-73.

Crawford, L. (2011) 'Adding Change Implementation to the Project Manager's 
Cite as: Pollack, J. Algeo, C. (2015) Should project management aspire to be an archetypal profession:

Evidence from Australian-based research. International Journal of Project Organization and Management, 7(4), 352-368. DOI: 10.1504/IJPOM.2015.073140

Toolkit', Paper presented at the PMOZ Conference, Sydney, Australia.

Crawford, L. and Nahmais, A. (2010) 'Competencies for Managing Change', International Journal of Project Management, Vol. 28, pp. 405-412.

Crawford, L. and Pollack, J. (2004) 'Hard and Soft Projects: A framework for analysis', International Journal of Project Management, Vol. 22, No. 8, pp. 645-653.

Crawford, L. and Pollack, J. (2007) 'How Generic are Project Management Knowledge and Practice', Project Management Journal, Vol. 38 No. 1, pp. 87-96.

Crawford, L., Pollack, J. and England, D. (2008) 'How Standard are Standards: An Analysis of Language Emphasis in Project Management Standards', Project Management Journal, Vol. 38, No. 3, pp. 6-21.

De Beelde, I. (2002) 'Creating a profession 'out of nothing'? The case of the Bengian auditing profession', Accounting, Organizations and Society, Vol. 27, pp. 447-470.

Floricel, S. and Miller, R. (2001) 'Strategizing for Anticipated Risks and Turbulence in Large-scale Engineering Projects', International Journal of Project Management, Vol. 19, No. 445-455.

Friedman, M. (1962) Capitalism and Freedom. University of Chicago Press, Chicago.

Gareis, R. (2008) 'Change management and projects: Guest Editorial', International Journal of Project Management, Vol. 26, pp. 771-772.

Gareis, R. (2010) 'Changes of Organizations by Projects', International Journal of Project Management, Vol. 28, pp. 314-327.

Garfein, S. and Sankaran, S. (2011) 'Work Preferences of Project and Program Managers, Change Managers and Project Team Members: The Importance of Knowing the Difference', Paper presented at the PMI Global Congress, Dallas, Texas.

Gravelle, H. (1985) 'Economic Analysis of Health Service Professions: a survey', Social Science and Medicine, Vol. 20, No. 10, pp. 1049-1061.

Helgadottir, H. (2008) 'The Ethical Dimension of Project Management', International Journal of Project Management, Vol. 26, pp. 743-748.

Hiatt, J. (2006) ADKAR: A model for change in business, government and our community, Prosci Learning Center Publications, Loveland, Colorado.

Hinings, C. (2001) 'Professions in Organizations', In Smelser, N. \& Baltes, P. (Eds.), International Encyclopaedia of the Social and Behavioral Sciences, Elsevier, pp. 12160-12166.

Hodgson, D. (2002) 'Disciplining the Professional: The case of project management', Journal of Management Studies, Vol. 39, No. 6, pp. 803-821.

Kotter, J. (1996) Leading Change, Harvard Business School Press, Boston, USA.

Long, M. and Rao, S. (1995) 'The Wealth Effects of Unethical Behaviour', Journal of Economics and Finance, Vol. 19, No. 2, pp. 65-73. 
Moline, J. (1986) 'Professions and Professionals: A Philosophical Examination of an Ideal', Social Science and Medicine, Vol. 22, No. 5, pp. 501-508.

Morris, P., Crawford, L., Hodgson, D., Shepherd, M. and Thomas, J. (2006)

'Exploring the role of formal bodies of knowledge in defining a profession - The case of project management,' International Journal of Project Management, Vol. 24, pp. 710-721.

Muzio, D., Hodgson, D., Faulconbridge, J., Beaverstock, J. and Hall, S. (2011) 'Towards corporate professionalization: The case of project management, management consultancy and executive search,' Current Sociology, Vol. 59, No. 4, pp. $443-464$

Professions Australia (PA) (1997) Definition of a Profession. Retrieved 28/11/2011, http://www.professions.com.au/definitionprofession.html

Peterson, D. (1976) 'Is Psychology a Profession?', American Psychologist, Vol. 31, No. 8, pp. 572-581.

PMI (1996) A Guide to the Project Management Body of Knowledge, Project Management Institute, Newtown Square, PA.

PMI (2000) A Guide to the Project Management Body of Knowledge, Project Management Institute, Newtown Square, PA.

PMI (2004) A Guide to the Project Management Body of Knowledge, Project Management Institute, Newtown Square, PA.

PMI (2008) A Guide to the Project Management Body of Knowledge, Project Management Institute, Newtown Square, PA.

PMI (2010) Complaint, Dispute, and Grievance Policy, Project Management Institute, Newtown Square, PA.

PMI (2011) Code of Ethics and Professional Conduct. Retrieved 28/11/2011, from http://www.pmi.org/About-Us/Ethics/Code-of-Ethics.aspx

Sheen, J. and Stevens, J. (2002) 'Aromatherapy as a Profession', International Journal of Aromatherapy, Vol. 12, No. 4, pp. 187-192.

Turner, J. and Cochrane, R.| (1993) 'Goals-and-methods Matrix: coping with projects with ill-defined goals and/or methods of achieving them', International Journal of Project Management, Vol. 11, pp. 93-101.

UK Government Cabinet Office (2002) Prince2®. Retrieved 28/11/2011, from http://www.cabinetoffice.gov.uk/resource-library/best-management-practice-bmpportfolio

Wang, X. (2002) 'Developing a True Sense of Professional Community: an important matter for pm professionalism', Project Management Journal, Vol. 33, No. 1, pp. 511.

Wang, X. and Armstrong, A. (2004) 'An empirical study of PM professionals commitment to their profession and employing organizations', International Journal of 
Project Management, Vol. 22, No. 5, pp. 377-386.

White, W. (1978) 'The Impact of Occupational Licensure of Clinical Laboratory Personnel', Journal of Human Resources, Vol. 13, No. 1, pp. 91-102.

Wilensky, H. (1964) 'The Professionalization of Everyone?' American Journal of Sociology, Vol. 70, No. 2, pp. 137-158.

WMA (2006) World Medical Association International Code of Medical Ethics, Retrieved 28/11/2011, from

http://www.wma.net/en/30publications/10policies/c8/index.html

Youker, R. (1999) 'The Difference Between Different Types of Projects', Paper presented at the 30th Annual Project Management Institute Seminar and Symposium, PA, USA.

Zwerman, B. and Thomas, J. (2006) 'Professionalisation of Project Management: what does it mean for practice?' In Dinsmore, P. \& Cabanis-Brewin, J. (Eds.), The AMA Handbook of Project Management, AMACOM, New York, pp. 236-247. 